\title{
Editorial
}

\section{Consanguineous marriages and their detrimental outcomes in Pakistan: an urgent need for appropriate measures}

\author{
Muhammad Anzar Ullah*, Aisha Maryam Husseni, Syed Uzair Mahmood
}

Jinnah Sindh Medical University, Karachi, Pakistan

\section{*Correspondence:}

Dr. Muhammad Anzar Ullah,

E-mail: ullahanzar610@gmail.com

Copyright: (c) the author(s), publisher and licensee Medip Academy. This is an open-access article distributed under the terms of the Creative Commons Attribution Non-Commercial License, which permits unrestricted non-commercial use, distribution, and reproduction in any medium, provided the original work is properly cited.

Consanguineous marriage is a union between first or second cousins, the former being more common. Cousin marriage, the more commonly used term, has been practiced over a long period of time but it is more popular in developing Asian countries especially Pakistan. ${ }^{1}$ Studies have shown that in Pakistan consanguinity was present in $60 \%$ of marriages out of which $80 \%$ were first cousins, further studies highlighted a similar rising trend of consanguinity among married couples. ${ }^{2-4}$ Pakistan is said to be the leading country to practice consanguinity with around $70 \%$ of marriages being consanguineous. Some regions of Pakistan have shown an alarming ratio of consanguineous marriages such as the Sargodha district of Punjab and Khyber Pakhtunkhwa.,

There are various factors that promote the practice of consanguineous marriages in Pakistan. Being an Islamic country opposite gender interaction is usually restricted only to close family members especially cousins. Therefore, arranged marriage is a major factor. Difficulty in finding a partner of same caste and status outside the family, the security of knowing the spouse and in-laws prior to marriage and strengthening interfamily ties are other important factors that have made consanguineous marriages so popular. ${ }^{4}$

Consanguineous marriages are also common in rural and less educated population which are the tribal areas of Pakistan such as the Khyber Pakhtunkhwa province. ${ }^{1,7}$ There has been a culture of dowry and very lavish weddings in the Pakistani community and considered as a matter of pride and honour, especially for the girl's family. However, it seems easier for blood relatives/cousins to negotiate on such expensive affairs. ${ }^{8}$

Consanguineous unions lead to some drastic outcomes that need to be highlighted. An increase in small birth size and neonatal mortality due to consanguineous marriages has been noticed; Consanguinity is also linked to underweight children (under five years old) being a major risk factor; A study from a rural area of Sindh stated that children who were underweight were 1.5 times more likely to have consanguineous parents compared to normal children. ${ }^{9,10}$

Cousin marriages are also linked to many rare recessive genetic disorders; members of the same family carry certain recessive genes that are usually supressed in their genetic makeup. When interfamily marriages take place, the chances of these genes to be expressed in the offspring is greatly increased due to a homozygous condition. ${ }^{11}$ Many serious diseases are also diagnosed later in childhood such as internal malformations, learning difficulties and many single gene disorders such as neurological disorders, thalassemia and cystic fibrosis. ${ }^{11}$ Autosomal recessive intellectual disorders are very common in populations with frequent parental consanguinity. ${ }^{12}$ Recently a team of Pakistani scientists concluded that the prevalence of mental retardation in the Pakistani population is due to cousin marriage, they also discovered 30 new genes in these children that were responsible for this abnormality. ${ }^{13}$ Every year 700 children are born with genetic disabilities due to cousin marriage and this was worse among British Pakistani communities. $^{14}$

Children with congenital heart diseases are 2.3 times more likely to be born of a consanguineous marriage as compared to those without a congenital heart disease. ${ }^{15}$ Punjab is the largest province of Pakistan and deafness consanguinity is very common in different castes of this province, the highest percentage of congenital deafness was found in the Rajput families. ${ }^{16}$ Consanguinity was also found associated with increased prevalence of 
bipolar disorder and its severity as highlighted in a case report. $^{17}$

There is an urgent need to address these crises. A nationwide approach is required to prevent these catastrophic outcomes in the future generations. Cousin marriages are a norm in the majority of our population, the masses being unaware of its consequences. Therefore, measures should be undertaken by not just the community but on the government level as well.

First of all, people need to be aware of all these possible diseases, awareness should spread through media and other sources of communication and special education camps should setup in the remote, inaccessible areas of Pakistan where the major part of this problem lies. Secondly, marriages should be the couple's decision entirely without any family pressure whatsoever.

Pre-pregnancy counselling sessions should be carried out as well as genetic screening. Pre-natal diagnostic tests should be regularly done. It should be a regular practice in Pakistan as well for couples who are first or second cousins to be tested for these traits, as well as prenatal diagnostic tests as per schedule. This practice is already done regularly in countries like Jordan, Saudi Arabia, Bahrain, Iran, Iraq and Turkey where consanguineous marriages are very high just like Pakistan. ${ }^{8}$

Cyprus has seen a decline in cousin marriages by passing certain laws prohibiting marriages between blood relations similarly China has reportedly annulled marriages of close relatives by law, such laws should also be passed in Pakistan. ${ }^{3,18}$

The literacy rate of Pakistan has slipped to 58\%, and $41 \%$ of girls in Pakistan fail to complete primary education. ${ }^{19,20}$ Therefore, education should now be the primary objective and steps should be taken urgently to promote education, consanguinity is observed mostly in an uneducated population, educating them especially girls will make them independent and enable them to make better decisions in life.

Pakistan has the second highest number of youngsters $(60 \%)$ in the world, who are considered as an asset of the county, and has a major role to play in its development. ${ }^{21}$ But a youth with severe intellectual disabilities and other genetic abnormalities will further increase the burden on this already struggling country. It's about time that this menace should be taken seriously before it's too late.

\section{REFERENCES}

1. Jones WG. Changing Marriage Patterns in Asia. ARI Working Paper \#131. 2010.

2. Hussain R, Bittles AH. The prevalence and demographic characteristics of consanguineous marriages in Pakistan. J Biosocial Sci. 1998;30(2):261-75.
3. Akram DS, Arif F, Fayyaz J. How Frequent Are Consanguineous Marriages? J Dow University Health Sci. 2008;2(2):76-9.

4. Qidwai W, Syed IA, Khan FM. Prevalence and perceptions about consanguineous marriages among patients presenting to family physicians, in 2001 at a Teaching Hospital in Karachi, Pakistan. Asia Pacific Family Med. 2003;2(1):27-31.

5. Pellissier H. Cousin Marriage - $70 \%$ in Pakistan Should it be Prohibited? Institute for Ethics and Emerging Technologies. 2012.

6. Hina S, Malik S. Pattern of Consanguinity and Inbreeding Coefficient in Sargodha District, Punjab, Pakistan. J Biosocial Sci Cambridge Univ Press. 2015;47(6):803-11.

7. Sthanadar AA, Bittles AH, Zahid M. Increasing Prevalence Of Consanguineous Marriage Confirmed In Khyber Pakhtunkhwa Province, Pakistan. J Biosoc Sci. 2016;48(3):418-20.

8. Hamamy H. Consanguineous marriages: Preconception consultation in primary health care settings. J Community Genetics. 2012;3(3):185-92.

9. Zakar R, Zakar MZ, Aqil N. Adverse birth outcomes associated with consanguineous marriage in Pakistan. Int Federation Gynaecol Obstet. 2014;127(2):211-2.

10. Hasnain SF, Hashmi SK. Consanguinity among the risk factors for underweight in children under five: a study from rural Sindh. J Ayub Med Coll, Abbottabad: JAMC. 2009;21(3):111-6.

11. Modell B, Darr A. Science and society: genetic counselling and customary consanguineous marriage. Nature Reviews Genetics. 2002;3(3):2259.

12. Musante L, Ropers HH. Genetics of recessive cognitive disorders. Trends in Genetics. 2014;30(1):32-9.

13. Junaidi I. Study finds 30 new genes that may cause intellectual disabilities. DAWN Pakistan. 2016.

14. Lefort R. 700 children born with genetic disabilities due to cousin marriages every year. The Telegraph. 2010.

15. Haq F, Jalil F, Hashmi S, Jumani M, Imdad A, Jabeen $\mathrm{M}$, et al. Risk factors predisposing to congenital heart defects. Annals of Pediatric Cardiology. 2011;4(2):117-21.

16. Ullah S, Aslamkhan M, Ali A, Idrees M. Causes of deafness in the Punjab region of Pakistan and the role of consanguinity. Public health. 2017;145:93-5.

17. Aadil M, Munir A, Arshad H, Tariq F, Anwar MJ, Amjad N, et al. Consanguinity Associated with Increased Prevalence and Severity of Bipolar Disorder in Pakistan: A Case Report Highlighting the Genetic Link. Cureus. 2017;9(7):e1467.

18. Zhu H. Arranged marriages annulled by law. China population today. 1996;13(3):15.

19. Haq R. Literacy rate in Pakistan slips by $2 \%$. The Express Tribune, Pakistan. 2017 May 26th;Sect. Business. 
20. Mussadaq M. Female illiteracy: $41 \%$ of Pakistani girls fail to complete primary school. The Express Tribune, Pakistan. 2011 July 20th.

21. Rizvi O. The youth in Pakistan. Daily Times. 2017.
Cite this article as: Ullah MA, Husseni AM,

Mahmood SU. Consanguineous marriages and their detrimental outcomes in Pakistan: an urgent need for appropriate measures. Int $\mathrm{J}$ Community Med Public Health 2018;5:1-3. 